\title{
Evaluation of facial attractiveness in black people according to the subjective facial analysis criteria
}

\author{
Andréa Reis de Melo', Ana Cláudia de Castro Ferreira Conti², Renata Rodrigues Almeida-Pedrin², \\ Victor Didier ${ }^{3}$, Danilo Pinelli Valarelli², Leopoldino Capelozza Filho²
}

DOI: $h t t p: / / d x . d o i . o r g / 10.1590 / 2177-6709.22 .1 .075-081$. oar

\begin{abstract}
Objective: The objective of this study was to evaluate the facial attractiveness in 30 black individuals, according to the Subjective Facial Analysis criteria. Methods: Frontal and profile view photographs of 30 black individuals were evaluated for facial attractiveness and classified as esthetically unpleasant, acceptable, or pleasant by 50 evaluators: the 30 individuals from the sample, 10 orthodontists, and 10 laymen. Besides assessing the facial attractiveness, the evaluators had to identify the structures responsible for the classification as unpleasant and pleasant. Intraexaminer agreement was assessed by using Spearman's correlation, correlation within each category using Kendall concordance coefficient, and correlation between the 3 categories using chi-square test and proportions. Results: Most of the frontal (53. 5\%) and profile view (54. 9\%) photographs were classified as esthetically acceptable. The structures most identified as esthetically unpleasant were the mouth, lips, and face, in the frontal view; and nose and chin in the profile view. The structures most identified as esthetically pleasant were harmony, face, and mouth, in the frontal view; and harmony and nose in the profile view. The ratings by the examiners in the sample and laymen groups showed statistically significant correlation in both views. The orthodontists agreed with the laymen on the evaluation of the frontal view and disagreed on profile view, especially regarding whether the images were esthetically unpleasant or acceptable. Conclusions: Based on these results, the evaluation of facial attractiveness according to the Subjective Facial Analysis criteria proved to be applicable and to have a subjective influence; therefore, it is suggested that the patient's opinion regarding the facial esthetics should be considered in orthodontic treatment planning.
\end{abstract}

Keywords: Orthodontics. Diagnosis. Face. Profile. Black.

Objetivo: avaliar, quanto à agradabilidade facial, uma amostra de 30 indivíduos negros, de acordo com os critérios da Análise Facial Subjetiva. Métodos: fotografias frontais e de perfil de 30 indivíduos negros foram avaliadas quanto à agradabilidade facial e classificadas como esteticamente desagradáveis, aceitáveis ou agradáveis, por 50 avaliadores, sendo: 30 indivíduos da amostra, 10 ortodontistas e 10 leigos. Além de avaliar a agradabilidade facial, os avaliadores tiveram que identificar as estruturas responsáveis pela classificação como desagradável ou agradável. A concordância intraexaminador foi avaliada por meio da correlação de Spearman. Já a correlação dentro de cada categoria foi analisada por meio do coeficiente de concordância de Kendall, e a correlação entre as três categorias foi estabelecida por meio dos testes qui-quadrado e de proporção. Resultados: a maioria das fotografias frontais $(53,5 \%)$ e de perfil $(54,9 \%)$ foi classificada como esteticamente aceitável. As estruturas mais identificadas como esteticamente desagradáveis foram: boca, lábios e rosto, na fotografia frontal; e nariz e queixo, na fotografia de perfil. As estruturas mais identificadas como esteticamente agradáveis foram: harmonia, rosto e boca, na fotografia de frente; e harmonia e nariz, na de perfil. As avaliações realizadas pelos examinadores nos grupos amostra e leigos mostraram uma correlação estatisticamente significativa em ambas as posições. Os ortodontistas concordaram com os leigos sobre a avaliação na perspectiva frontal e discordaram sobre a de perfil, especialmente no que diz respeito às imagens consideradas esteticamente desagradáveis ou aceitáveis. Conclusões: com base nesses resultados, a avaliação da agradabilidade facial, de acordo com critérios da Análise Facial Subjetiva, provou ser aplicável e ter uma influência subjetiva. Assim, sugere-se que a opinião do paciente sobre a estética facial seja considerada no planejamento do tratamento ortodôntico.

Palavras-chave: Ortodontia. Diagnóstico. Face. Perfil. Negro.

\footnotetext{
${ }^{1}$ Universidade Sagrado Coração, Dental School, Department of Orthodontics, Bauru, São Paulo, Brazil.

${ }^{2}$ Assistant Professor, Universidade Sagrado Coração, Dental School, Department of Orthodontics, Bauru, São Paulo, Brazil.

${ }^{3}$ Graduate student, Universidade Sagrado Coração, Dental School, Department of Orthodontics, Bauru, São Paulo, Brazil.
}

Contact address: Andréa Reis de Melo

Rua Irmã Arminda, 10-50, Jardim Brasil, Bauru/SP, Brasil CEP: 17.011-160 - E-mail: andreamelossa@yahoo.com. br
How to cite this article: R, Conti ACCF, Almeida-Pedrin RR, Didier V, Valarelli DP, Capelozza Filho L. Evaluation of facial attractiveness in black people according to the subjective facial analysis criteria. Dental Press J Orthod. 2017 Jan-Feb;22(1):75-81.

DOI: http://dx.doi.org/10.1590/2177-6709.22.1.075-081.oar

Submitted: May 18, 2016 - Revised and accepted: August 27, 2016

» The authors report no commercial, proprietary or financial interest in the products or companies described in this article.

» Patients displayed in this article previously approved the use of their facial and intraoral photographs. 


\section{INTRODUCTION}

In Orthodontics, diagnosis is made on the basis of anamnesis; clinical examination; facial, cephalometric and cast models analysis. The facial analysis is reported in the literature since Angle ${ }^{1}$ considered Apollo Belvedere's profile as the ideal, but soon admitted that there were other ideally beautiful faces ${ }^{2}$ that orthodontists should be able to identify. $3,4,5$

Since the advent of cephalometry, lateral radiographs of the face are being used to analyze the facial profile. ${ }^{4,6,7}$ Further, soft tissue analysis shows individual and race variations in facial profiles. ${ }^{8,9,10}$ Studies evaluating lateral radiographs of the face ${ }^{11,12,13}$ showed that black individuals have a bimaxillary protrusion. Similarly, another study ${ }^{11}$ that evaluated 100 photographs, reported that black individuals, particularly men, have a more protrusive soft tissue profile than Caucasians. Sutter and Turley ${ }^{15}$ evaluated 120 pictures of black and Caucasian women, both models and non-models, from fashion magazines. They concluded that the facial profiles of black models and non-models were similar, but those of the Caucasian women were significantly different, with models presenting more prominent lips.

To evaluate the changes in the profiles of black American women, Yehezkel and Turley ${ }^{16}$ evaluated 119 photographs from fashion magazines published in the 1940s through the 1990s and found that in the last three decades, the lips tended to be more prominent and anteriorly positioned, and profile convexity increased. In another study, ${ }^{17} 30$ silhouettes of black Americans and 30 Caucasians were evaluated by black and Caucasians orthodontists and layperson, and all evaluators preferred a more convex profile and greater lip protrusion for black individuals.

A new facial classification, based on growth pattern was proposed by Capelozza Filho. ${ }^{18}$ This classification system assess the facial morphology in all diagnostic tests, including photographs, radiographs, and cast models. Morphological analysis of the face, in frontal and profile views, is the main diagnostic tool to determine the Facial Pattern: I, II, III, Long Face, or Short Face. ${ }^{18}$ The Subjective Facial Analysis ${ }^{19}$ involves the esthetic evaluation of facial characteristics, as commonly is performed by individuals in the society. Based on this analysis, we routinely classify individuals as esthetically unpleasant, esthet- ically acceptable, and esthetically pleasant. This last facial analysis is more important because the facial attractiveness of people is judged by all as the harmony of facial characteristics, regardless the facial growth and skeletal disproportion.

The main objective of this study was to understand the preferred esthetic standards for black individuals, from the perspective of their own opinion (black people from the sample), orthodontists and lay people. Another objective was to identify the most important facial features responsible for the attractiveness. Accurate diagnosis requires a clear understanding of what is considered normal, and it is essential to establish a consensus regarding the goals between doctors and patients, to achieve the most esthetic treatment results.

\section{MATERIAL AND METHODS}

The research project was approved by the Research Ethics Committee of Universidade do Sagrado Coração (protocol \#499.996), and all individuals in the sample signed an informed consent.

The sample comprised 30 Brazilian black individuals (15 males and 15 females), mean age of 31.19 years, selected from the staff and patients of a medical center, and students from a dance school, according to the Subjective Facial Analysis criteria ${ }^{19}$. The sample had lip competence, no skeletal discrepancies or asymmetries, and no previous facial or orthognathic surgery and were available for participation.

Standardized frontal and profile photographs ${ }^{19,20}$ of all individuals were obtained. They were printed in a $10 \times 15 \mathrm{~cm}$ format and randomly placed in two albums: frontal (Fig 1) and profile (Fig 2) images.

The photographs were assessed by 50 evaluators: 30 individuals from the sample, 10 orthodontists selected according to their experience (minimum 10 years), and 10 laymen (individuals with no orthodontic knowledge), with ages ranging between 14.05 and 71 years and a mean age of 37.03 years.

The classification of the pictures followed the pattern described by Reis et al. ${ }^{19}$ The evaluators were asked to look at each picture for 30 seconds, without being allowed to return to the previous picture - to avoid comparisons - , and assign a score (1-9) according to the following criteria: scores $1,2,3=$ esthetically unpleasant; scores 4, 5, 6 = esthetically acceptable and scores $7,8,9=$ esthetically pleasant. 


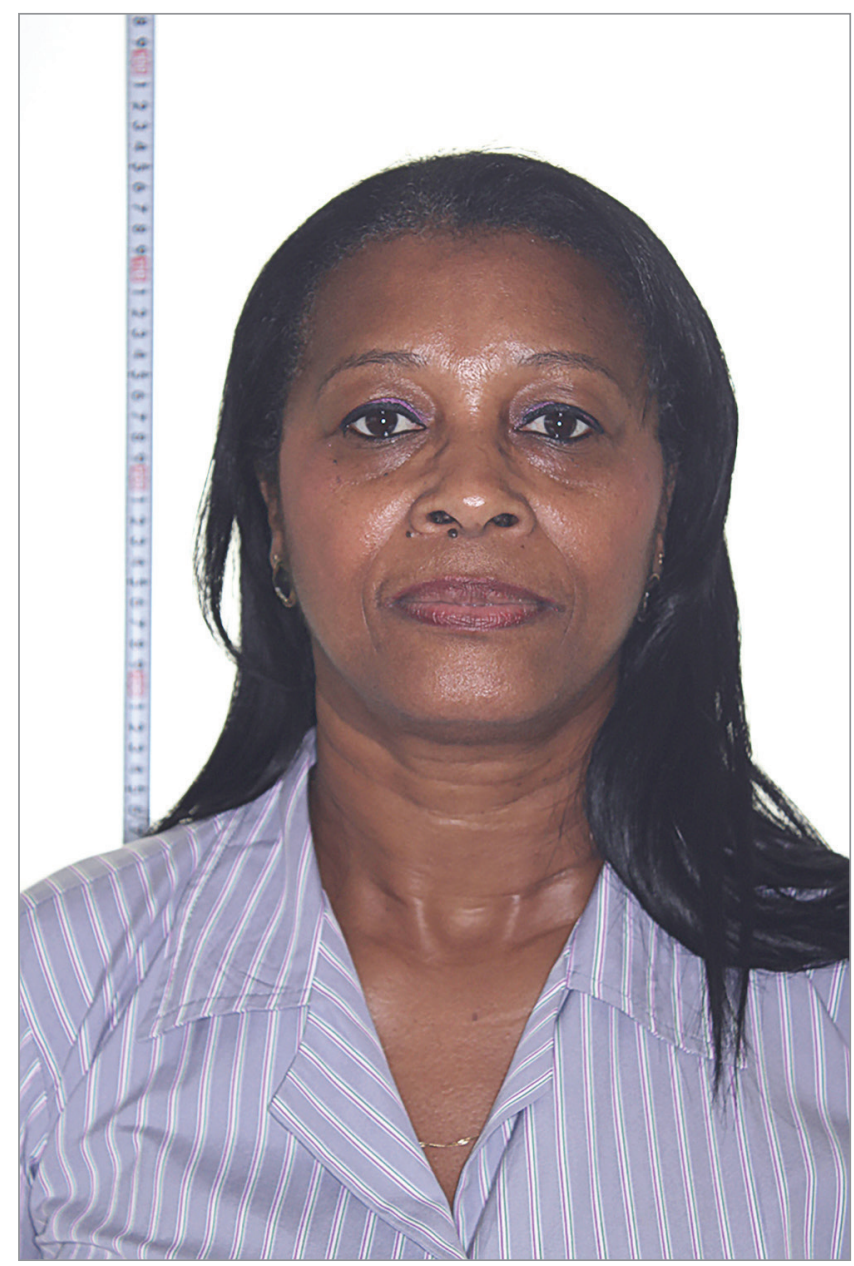

Figure 1 - Frontal view photograph from an individual of the sample.

In the photographs scored as $1-3$, the evaluators were required to mention the facial feature that they found unpleasant, and conversely, to mention the feature that they found pleasant in photographs scored as 7-9. The photographs were evaluated twice by three individuals of each group of evaluators, with a 30-day interval between assessments.

\section{STATISTICAL ANALYSIS}

Intraexaminer agreement was assessed using Spearman's correlation, and the correlation between the three categories was assessed using chi-square test and proportion test.

For all tests, a significance level of $p<0.05$ was used. All statistical procedures were performed with the Statistica software, version 12 (StatSoft Inc., Tulsa, USA).

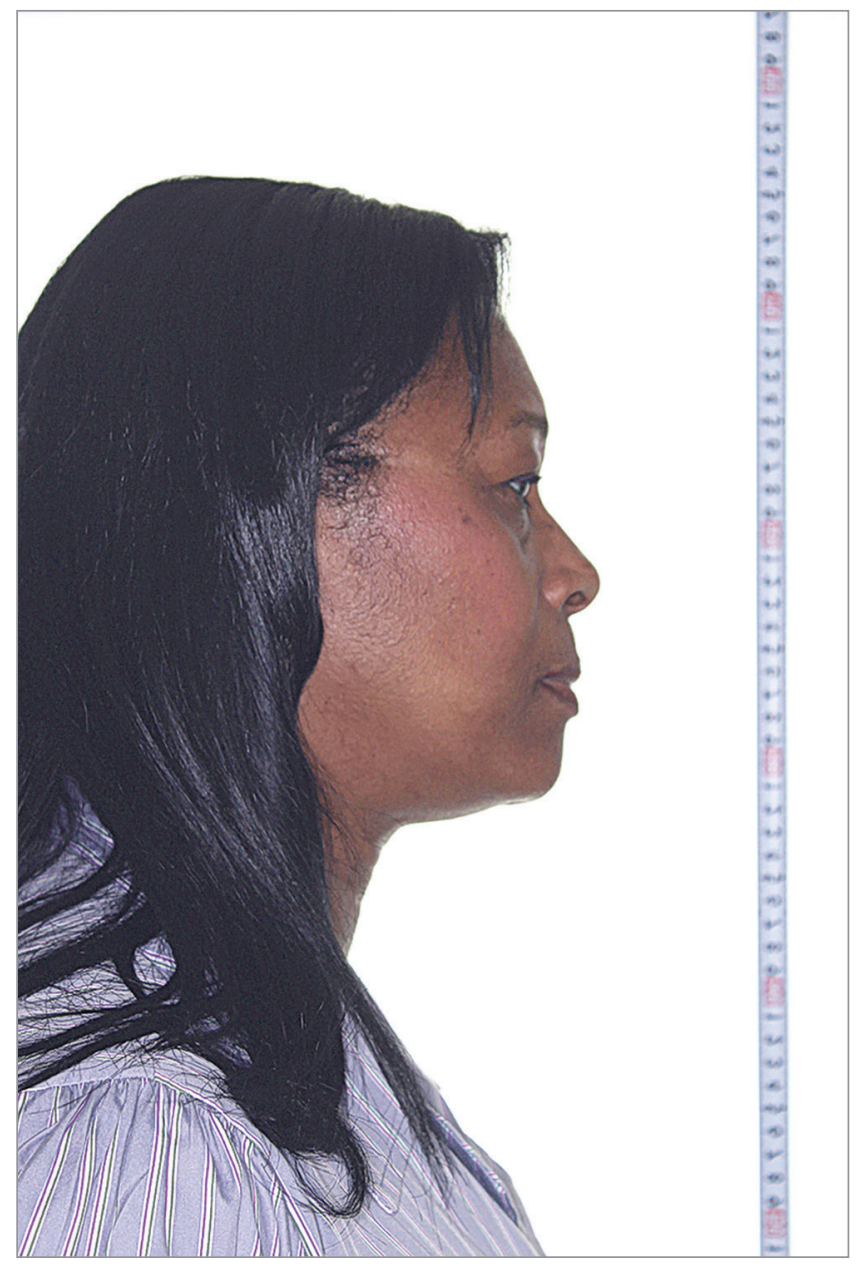

Figure 2 - Profile view photograph from an individual of the sample.

\section{RESULTS}

Data are presented as absolute frequency (n) and relative frequency (\%). To evaluate intra-evaluator correlation, it was used the Spearman correlation coefficient, which ranged from 0.37 to 0.57 , and at $p<0.001$, showing a statistically significant correlation between the first and the second evaluation across all reviewers. To compare among the three categories of evaluators, it was used the chi-square test and the proportions test, and it was found that most of the photographs were classified as acceptable in both positions (frontal and profile) (Tables 1 and 2).

In the frontal and profile views, the most important structures responsible for facial unpleasant are described in Tables 3 and 4 . In the frontal and profile views, the most important structures responsible for facial pleasant are described in Tables 5 and 6 . 
Table 1 - Comparison of ratings of each category of evaluator.

\begin{tabular}{|c|c|c|c|c|}
\hline Position & Category & Unpleasant & Acceptable & Pleasant \\
\hline \multirow{4}{*}{ Frontal } & Sample & $18.3 \%^{a}$ & $56.8 \%^{a}$ & $24.9 \%^{\mathrm{a}}$ \\
\hline & Laymen & $23.3 \%$ ab & $53.0 \%{ }^{\mathrm{ab}}$ & $23.7 \%^{a}$ \\
\hline & Orthodontists & $26.7 \%^{b}$ & $44.3 \%^{b}$ & $29.0 \%^{a}$ \\
\hline & $p$ & $0.005^{*}$ & $0.001^{*}$ & 0.267 \\
\hline \multirow{4}{*}{ Profile } & Sample & $19.1 \%^{\mathrm{a}}$ & $60.0 \%^{a}$ & $20.9 \%^{a}$ \\
\hline & Laymen & $23.0 \%^{a}$ & $53.3 \%^{\text {a }}$ & $23.7 \%^{a}$ \\
\hline & Orthodontists & $38.7 \%^{b}$ & $41.3 \%^{b}$ & $20.0 \%^{a}$ \\
\hline & $p$ & $<0.001^{*}$ & $<0.001^{*}$ & 0.498 \\
\hline
\end{tabular}

* Statistically significant difference $(p<0.05)$. Categories with the same letter have no significant difference between them.

Table 2 - Comparison between the positions within each category of evaluator.

\begin{tabular}{|c|c|c|c|c|c|}
\hline Category & Position & Unpleasant & Acceptable & Pleasant & $\mathbf{p}$ \\
\hline \multirow{2}{*}{ Sample } & Frontal & $18.3 \%$ & $56.8 \%$ & $24.9 \%$ & \multirow{2}{*}{0.129} \\
\hline & Profile & $19.1 \%$ & $60.0 \%$ & $20.9 \%$ & \\
\hline \multirow{2}{*}{ Laymen } & Frontal & $23.3 \%$ & $53.0 \%$ & $23.7 \%$ & \multirow{2}{*}{0.995} \\
\hline & Profile & $23.0 \%$ & $53.3 \%$ & $23.7 \%$ & \\
\hline \multirow{2}{*}{ Orthodontists } & Frontal & $26.7 \%^{a}$ & $44.3 \%^{a}$ & $29.0 \%$ व & \multirow{2}{*}{$0.003^{*}$} \\
\hline & Profile & $38.7 \%^{b}$ & $41.3 \%^{\mathrm{a}}$ & $20.0 \%$ b & \\
\hline
\end{tabular}

* Statistically significant difference $(p<0.05)$. Positions with the same letter have no significant difference between them.

Table 3 - Frontal view structures recognized as esthetically unpleasant.

\begin{tabular}{|c|c|c|c|c|}
\hline \multirow{2}{*}{ Reason } & \multicolumn{3}{|c|}{ Category } & \multirow{2}{*}{ TOTAL } \\
\hline & Sample & Laymen & Orthodontists & \\
\hline Mouth & 37 & 9 & - & 46 \\
\hline Nose & 29 & 6 & 3 & 38 \\
\hline Ears & 24 & 5 & 1 & 30 \\
\hline Eyes & 12 & 6 & 3 & 21 \\
\hline Lips & 5 & 4 & 9 & 18 \\
\hline Face & 2 & 1 & 11 & 14 \\
\hline Chin & 8 & 4 & 1 & 13 \\
\hline Cheeks & 7 & 2 & - & 9 \\
\hline Whole face & 9 & - & - & 9 \\
\hline Maxilla & 5 & - & - & 5 \\
\hline Upper lip & 2 & 1 & 1 & 4 \\
\hline Lower lip & - & 3 & 1 & 4 \\
\hline Hair & 2 & 2 & - & 4 \\
\hline $\begin{array}{l}\text { Bimaxillary } \\
\text { protrusion }\end{array}$ & - & - & 4 & 4 \\
\hline Long face & - & - & 4 & 4 \\
\hline Lower third of face & - & - & 3 & 3 \\
\hline Look & 1 & 1 & - & 2 \\
\hline Jowl & - & 1 & 1 & 2 \\
\hline Eyebrows & 1 & - & 1 & 2 \\
\hline Face length & 1 & 1 & - & 2 \\
\hline Mandible & - & - & 1 & 1 \\
\hline Head & - & - & 1 & 1 \\
\hline Protrusive lips & - & - & 1 & 1 \\
\hline Middle third of face & - & - & 1 & 1 \\
\hline
\end{tabular}

Table 4 - Profile view structures recognized as esthetically unpleasant.

\begin{tabular}{|c|c|c|c|c|}
\hline \multirow{2}{*}{ Reason } & \multicolumn{3}{|c|}{ Category } & \multirow{2}{*}{ TOTAL } \\
\hline & Sample & Laymen & Orthodontists & \\
\hline Nose & 43 & 10 & 1 & 54 \\
\hline Chin & 20 & 23 & 5 & 48 \\
\hline Mouth & 37 & 3 & - & 40 \\
\hline Profile & 2 & - & 16 & 18 \\
\hline Lips & 7 & 1 & 7 & 15 \\
\hline Lower lip & - & 6 & 6 & 12 \\
\hline Mandible & - & - & 12 & 12 \\
\hline Lower third of face & - & - & 9 & 9 \\
\hline Whole face & 7 & - & 1 & 8 \\
\hline Jowl & 5 & - & 2 & 7 \\
\hline $\begin{array}{l}\text { Bimaxillary } \\
\text { protrusion }\end{array}$ & - & - & 7 & 7 \\
\hline Cheeks & 4 & 1 & - & 5 \\
\hline Ears & 5 & - & - & 5 \\
\hline Hair & 2 & 2 & - & 4 \\
\hline Neck & 3 & - & 1 & 4 \\
\hline Maxilla & 2 & - & 1 & 3 \\
\hline Face & 3 & - & - & 3 \\
\hline Chin-neck line & - & - & 2 & 2 \\
\hline Head & 2 & - & - & 2 \\
\hline Long face & - & - & 2 & 2 \\
\hline Middle third of face & - & - & 2 & 2 \\
\hline Upper lip & - & 1 & - & 1 \\
\hline Eyes & - & 1 & - & 1 \\
\hline Eyebrows & 1 & - & - & 1 \\
\hline Countenance & - & 1 & - & 1 \\
\hline Mentolabial sulcus & - & - & 1 & 1 \\
\hline
\end{tabular}


Table 5 - Frontal view structures recognized as esthetically pleasant

\begin{tabular}{|c|c|c|c|c|}
\hline \multirow{2}{*}{ Reason } & \multicolumn{3}{|c|}{ Category } & \multirow{2}{*}{ TOTAL } \\
\hline & Sample & Laymen & Orthodontists & \\
\hline Harmony & 28 & 6 & 65 & 99 \\
\hline Face & 75 & 15 & 9 & 99 \\
\hline Mouth & 26 & 14 & - & 40 \\
\hline Eyes & 24 & 6 & 4 & 34 \\
\hline Lips & 14 & 1 & 1 & 16 \\
\hline Nose & 11 & 2 & - & 13 \\
\hline Chin & 13 & - & - & 13 \\
\hline Look & 1 & 5 & - & 6 \\
\hline Symmetry & 2 & 1 & 1 & 4 \\
\hline Countenance & - & 4 & - & 4 \\
\hline Sympathy & - & 3 & - & 3 \\
\hline Cheeks & 1 & 1 & - & 2 \\
\hline Maxilla & 1 & - & - & 1 \\
\hline Mandible & - & - & 1 & 1 \\
\hline
\end{tabular}

Table 6 - Profile view structures recognized as esthetically pleasant.

\begin{tabular}{|c|c|c|c|c|}
\hline \multirow{2}{*}{ Reason } & \multicolumn{3}{|c|}{ Category } & \multirow{2}{*}{ TOTAL } \\
\hline & Sample & Laymen & Orthodontists & \\
\hline Profile & 50 & 2 & 5 & 57 \\
\hline Harmony & - & 12 & 36 & 48 \\
\hline Nose & 25 & 9 & - & 34 \\
\hline Chin & 12 & 7 & - & 19 \\
\hline Mouth & 16 & 3 & - & 19 \\
\hline Face & 27 & 8 & 1 & 36 \\
\hline Eye & 11 & 1 & - & 12 \\
\hline Lips & 5 & - & 2 & 7 \\
\hline Look & 2 & - & - & 2 \\
\hline Lower lip & - & 1 & - & 1 \\
\hline Neck & 1 & - & - & 1 \\
\hline Countenance & - & 1 & - & 1 \\
\hline
\end{tabular}

\section{DISCUSSION}

Facial esthetics is one of the main reasons for seeking orthodontic treatment. ${ }^{21,22}$ Since beauty is subjective, ${ }^{14,21}$ both morphological and subjective facial analysis are essential for diagnosis and orthodontic planning; morphological facial analysis assesses the facial growth pattern ${ }^{18}$ while subjective facial analysis assesses the patients' selfperception as well as their perception of how the society sees them. ${ }^{19}$ The great miscegenation of the Brazilian population and the lack of studies in black people was the main reason to conduct this study to get important points to be considered in subjective facial analysis.

The results show that most of the sample was classified as esthetically acceptable by the three categories of evaluators, which was comparable to the findings of other studies (Tables 1 and 2). ${ }^{19,23,24,25}$

The sample group classified $18.3 \%$ of the frontal view photographs as unpleasant, $56.8 \%$ as acceptable, $24.9 \%$ as pleasant; and $19,1 \%$ of the profile view photographs as unpleasant, $60 \%$ as acceptable, and $20.9 \%$ as pleasant, with no statistically significant difference (Table 1). The laymen classified $23.3 \%$ of the frontal view photographs as unpleasant, $53 \%$ as acceptable, and $23.7 \%$ as pleasant; and $23 \%$ of the profile view photographs as unpleasant, $53.3 \%$ as acceptable, and $23.7 \%$ as pleasant, with no statistically significant difference (Table 1). The orthodontists classified $26.7 \%$ of the frontal view photographs as unpleasant, $44.3 \%$ as acceptable, and $29 \%$ as pleasant; and $38.7 \%$ 
of the profile view photographs as unpleasant, $41.3 \%$ as acceptable, and $20 \%$ as pleasant (Table 1). This group showed a statistically significant difference, indicating that the criteria of choice in this group was subjective. ${ }^{26}$ Perhaps this difference is because the training of the orthodontists makes them more selective while assessing profile view pictures. As reported by Thomas, ${ }^{12}$ the profile view is better at representing the skeletal discrepancies than the frontal view. However, Cavichiolo et $\mathrm{al}^{27}$ reported contrasting results that the laymen were more critical than orthodontists for the profile view photographs, while assessing facial attractiveness in subjects with Patterns II and III. Therefore, it is possible that the criterion of analysis is influenced by the training of orthodontists, justifying a greater tolerance for eventual errors.

The sample group classified $18.3 \%$ of the frontal view photographs and $19.1 \%$ of the profile view photographs as unpleasant (Table 2). This percentage, although is the lowest among evaluators, leads us to question whether the inclusion criteria for collecting a sample representative of the face of a standard black Brazilian was correct. However, on investigating, we found that this classification is affected by many subjective factors as well as other features over which orthodontic treatment has no influence, such as ears, forehead, cheek, hair, eyes, eyebrows, head, and neck. From a technical perspective, features such as the nose, mouth, and chin indicated as esthetically unpleasant should be given more importance during clinical evaluation and classification of patients for diagnosis and treatment.

In frontal view photographs, mouth, nose, ear, and eye were most frequently cited as esthetically unpleasant by the sample group; mouth, nose, eye, and ear by laymen; and face and lips by orthodontists (Table 3). The features reported as unpleasant by the orthodontists were surprising because they were rather nonspecific, as opposed to those reported by the sample group, who mentioned much more specific features, sometimes mentioning more than one feature for an individual.

In profile view photographs, nose, mouth, and chin were most frequently cited as esthetically unpleasant by the sample group; chin and nose by laymen; and profile, mandible, lower face and bimaxillary protrusion, by orthodontists (Table 4). These results are consistent with the findings of Reis et al, ${ }^{19}$ who reported that the nose and chin were the most cited features, and those of Almeida et $\mathrm{al}^{23}$ and Ferrari Jr et al, ${ }^{24}$ who reported that the nose is the second most mentioned structure. Overall, the profile view was more frequently cited as responsible for the unpleasant classification, perhaps because it shows a global view of the individual. Bimaxillary protrusion was not mentioned by any other category of evaluators, except orthodontists, perhaps because it is a technical term.

In frontal view photographs, face, harmony, mouth, eye, lips, chin, and nose were most frequently cited as esthetically pleasant by the sample group; face, mouth, harmony, and eye by laymen; and harmony, face, and eye by orthodontists (Table 5). This result indicates that the perception of beauty depends more on the whole face rather than on individual structures, as supported by findings of Dierkes $^{5}$ and Okuyama et al. ${ }^{26}$

In profile view photographs, profile, face, nose, mouth, and chin were most frequently cited as esthetically pleasant by the sample group; harmony, nose, and face by laymen; and harmony and profile by orthodontists (Table 6). These results indicate that in the profile view, it is difficult to identify the feature responsible for the perception of beauty. However, the fact that the sample group chose the profile view to be more representative of beauty - in despite that the orthodontists identified bimaxillary protrusion as representative of esthetically unpleasant structures - means that protruding profile is considered more pleasing in a black population. These findings corroborate with other studies, $15,16,17$ which showed that a more prominent profile was considered more beautiful, especially for women.

\section{CONCLUSIONS}

According to the judgement by the evaluators, black individuals were classified as acceptable facial attractiveness. The best results of acceptable and pleasant facial attractiveness were found by the group of non-orthodontists. It was not possible to identify the most important feature responsible for facial attractiveness, in the frontal and profile view. These results highlight the importance of the individual's opinion in relation to facial esthetics when planning orthodontic treatment, because individuals generally seek orthodontic treatment looking for an esthetic improvement in their smile and face.

\section{Authors contribution}

Conception or design of the study: LCF. Data acquisition, analysis or interpretation: ARM, RRAP Writing the article: ARM, VD, DPV, LCF. Critical revision of the article: ACCFC, RRAP, DPV. Final approval of the article: ACCFC, RRAP. Overall responsibility: ARM. 


\section{REFERENCES}

1. Angle EH. Classification of malocclusion. Dent Cosmos. 1899:41(2):248-65

2. Angle EH. Treatment of malocclusion of the teeth. Angle's system. 7th ed. Philadelphia: S. S. White; 1907

3. Herzberg BL. Facial esthetic in relation to orthodontic treatment. Angle Orthod. 1952:22(1):3-22.

4. Hambletom RS. The soft tissue covering of the skeletal face as related to orthodontic problems. Am J Orthod. 1964;50(6):405-20.

5. Dierkes JM. The beauty of the face: an orthodontic perspective. J Am Dent Assoc. 1987 Dec:Spec No:89E-95E.

6. Burstone CJ. Integumental contour and extension patterns. Angle Orthod 1959:29(2):93-104

7. Neger M, Newark NJ. A quantitative method for the evaluation of the softtissue facial profile. Am J Orthod. 1959:45(10):738-51.

8. Downs WB. Analysis of the Dentofacial Profile. Angle Orthod. 1956;26(4):191-212.

9. Cunningham MR. Measuring the physical in physical attractiveness quasi-experiments on the sociobiology of female facial beauty. J Pers Soc Psychol. 1986:50(5):925-35

10. Vedovello Filho M, Rossi ACS, lague Neto G, Vedovello SAS, Valdrighi HC Análise facial e sua importância no diagnóstico ortodôntico. J Bras Ortodon Ortop Facial. 2002; 7(39):218-25

11. Peck H, Peck S. A concept of facial esthetics. Angle Orthod. 1970;40(4):284318.

12. Thomas RG. An evaluation of the soft-tissue facial profile in the North American black woman. Am J Orthod. 1979;76(1):84-9

13. Freitas LMA, Freitas KMS, Pinzan A, Janson G, Freitas MR. A comparison of skeletal, dentoalveolar and soft tissue characteristics in white and black Brazilian subjects. J Appl Oral Sci. 2010;18(2):135-42.

14. Sushner NI. A photographic study of the soft-tissue profile of the Negro population. Am J Orthod. 1977 Oct;72(4):373-85.

15. Sutter RE Jr, Turley PK. Soft tissue evaluation of contemporary Caucasian and African American female facial profiles. Angle Orthod. 1998:68(6):487-

16. Yehezkel S, Turley PK. Changes in the African American female profile as depicted in fashion magazines during the 20th century. Am J Orthod Dentofacial Orthop. 2004 Apr;125(4):407-17.
17. Hall D, Taylor RW, Jacobson A, Sadowsky PL, Bartolucci A. The perception of optimal profile in African Americans versus white Americans as assessed by orthodontists and the lay public. Am J Orthod Dentofacial Orthop. 2000 Nov:118(5):514-25

18. Capelozza Filho L. Diagnóstico em Ortodontia. Maringá: Dental Press; 2004

19. Reis SAB, Abrão J, Capelozza Filho L, Claro CAA. Análise Facial Subjetiva. Rev Dental Press Ortod Ortop Facial. 2006;11(5):159-72

20. Capelozza Filho L, Cardoso MA, An TL, Lauris JRP. Proposta para classificação, segundo a severidade, dos indivíduos portadores de más oclusões do Padrão Face Longa. Rev Dental Press Ortod Ortop Facial. 2007:12(4):124-58

21. Skinazi GL, Lindauer SJ, Isaacson RJ. Chin, nose, and lips. Normal ratios in young men and women. Am J Orthod Dentofacial Orthop. 1994 Nov:106(5):518-23.

22. Salmória I, Furtado A, Rosário HD, Furtado GC, Paranhos LR. Análise Facial de Arnett e Bergman comparada a percepção estética de leigos e cirurgiões-dentistas (clínicos gerais e ortodontistas). Biosci J. 2014:30(1):297303

23. Almeida AM, Capelozza Filho L, Ferrari Junior FM, Lauris RCMC, Garib DG Evaluation of facial esthetics in rehabilitated adults with complete unilateral cleft lip and palate: a comparison between professionals with and without experience in oral cleft rehabilitation. ISRN Plast Surg. 2013:(2013):2-7.

24. Ferrari Júnior FM, Ayub PV, Capelozza Filho L, Pereira Lauris JR, Garib DG. Esthetic evaluation of the facial profile in rehabilitated adults with complete bilateral cleft lip and palate. J Oral Maxillofac Surg. 2015 Jan;73(1):169.e1-6.

25. Morosini IAC, Peron APLM, Correia KR, Moresca R. Study of face pleasantness using facial analysis in standardized frontal photographs Dental Press J Orthod. 2012;17(5):24-34

26. Okuyama CC, Martins DR. Preferência do perfil facial tegumentar, em joven leucodermas, melanodermas e xantodermas de ambos os sexos, avaliados por ortodontistas, leigos e artistas plásticos. Ortodontia. 1997;30(1):6-18.

27. Cavichiolo JC, Salazar M, Cuoghi AO, Mendonça MR, Furquim LZ. Avaliação da agradabilidade facial de pacientes portadores de padrão facial II e III por ortodontistas e leigos. Odonto. 2010:18(36):73-81 